\title{
A Case Report of Papillary Renal Cell Carcinoma Seeding along a Percutaneous Biopsy Tract
}

\author{
Christine Busset, Sandrine Vijgen, Benoît Lhermitte, Pu Yan* \\ Institute of Pathology, University of Lausanne, Lausanne, Switzerland \\ Email: *Pu.Yan@synlab.com
}

How to cite this paper: Busset, C., Vijgen, S., Lhermitte, B. and Yan, P. (2018) A Case Report of Papillary Renal Cell Carcinoma Seeding along a Percutaneous Biopsy Tract. Open Journal of Pathology, 8, 139-146. https://doi.org/10.4236/ojpathology.2018.8 $\underline{4016}$

Received: August 29, 2018

Accepted: October 22, 2018

Published: October 25, 2018

Copyright $\odot 2018$ by authors and Scientific Research Publishing Inc. This work is licensed under the Creative Commons Attribution International License (CC BY 4.0).

http://creativecommons.org/licenses/by/4.0/

\begin{abstract}
We report a rare case of a papillary renal cell carcinoma seeding along a percutaneous biopsy tract detected at the time of partial nephrectomy in a 51-year-old man with a $3.5 \mathrm{~cm}$ renal mass discovered on computed tomography scan (CT scan). Although renal percutaneous biopsy is now considered as an accurate and safe technique to provide valuable diagnostic information for indeterminate renal lesions, some inherent risks have been reported to associate with this procedure. One of the risks is tumor needle tract seeding, which is a very rare complication of renal percutaneous biopsy. Our well-documented case report could provide some useful information to evaluate the prognosis of patients with tumor seeding along a percutaneous biopsy tract.
\end{abstract}

\section{Keywords}

Kidney Neoplasms, Biopsy, Seeding

\section{Introduction}

In the past few years, with the increased use of cross sectional imaging, many small renal masses are discovered in asymptomatic patients. Some of those small renal masses do not present radiological criteria allowing determining the nature of these tumors. $15 \%$ to $35 \%$ of these incidentally discovered small renal masses are benign after final histological diagnosis [1]. A more precise pretherapeutic diagnosis is now required in order to avoid unnecessary surgical removal. Therefore, percutaneous renal biopsy plays an important role in the management algorithm for those patients [2] [3] [4]. Recent assessments of the safety of renal mass biopsies state that the overall complication rates range from $1.4 \%$ to $4.7 \%$, with major complications reported only in $0.46 \%$ of all patients undergoing renal mass biopsies [4] [5] [6] [7]. The major complications are tumor 
tract seeding, bleeding, arteriovenous fistula, infection and pneumothorax. Needle tract seeding refers to implantation of tumor cells by contamination when instruments like biopsy needles are used to examine, excise or remove a tumor. It can later manifest as a tumor. Some authors believe that tumor seeding may lead to change the tumor stage, convert a resectable tumor into an inoperable one and then worsen the prognosis [8]. The tumor tract seeding has been estimated to be lower than $0.01 \%$ [9]. Since 1977 to date, only 15 cases of tumor tract seeding have been reported in the literature [5] [6] [10]-[20]. We describe here an another well documented case, which is the only one encountered in our institution in 205 cases of renal biopsies followed by surgery in 17 years, establishing a frequency of tumor tract seeding of $0.48 \%$.

\section{Clinical Case}

I represent and warrant that investigations involving human subjects received the appropriate institutional approval.

A 51-year-old man with no prior medical history presented with a right flank pain. The CT-scan discovered a $3.5 \mathrm{~cm}$ solid renal mass, strictly limited to the kidney (Figure 1). The patient also had a $3.5 \mathrm{~cm}$ cystic lesion that was not explored but a marsupialization of the cyst was done. An ultrasound-guided biopsy of the solid mass was performed. The lesion was accessed using an 18-gauge needle with coaxial sheath. 2 passes were made to obtain 8 cores, measuring 0.3 and $0.4 \mathrm{~cm}$ in length. Pathological analysis of the biopsy specimens showed a papillary renal cell carcinoma, probably type 1 . No adjuvant treatment was administered. The patient underwent partial nephrectomy a month after diagnosis. No problems occurred post-operatively and no other treatment was prescribed. The analysis of the surgical specimen showed a well circumscribed firm mass measuring $4.2 \times 3.9 \times 3.7 \mathrm{~cm}$ and showing a yellow colour, without necrosis. The renal capsule overlying the tumor mass was intact. Microscopically, this well

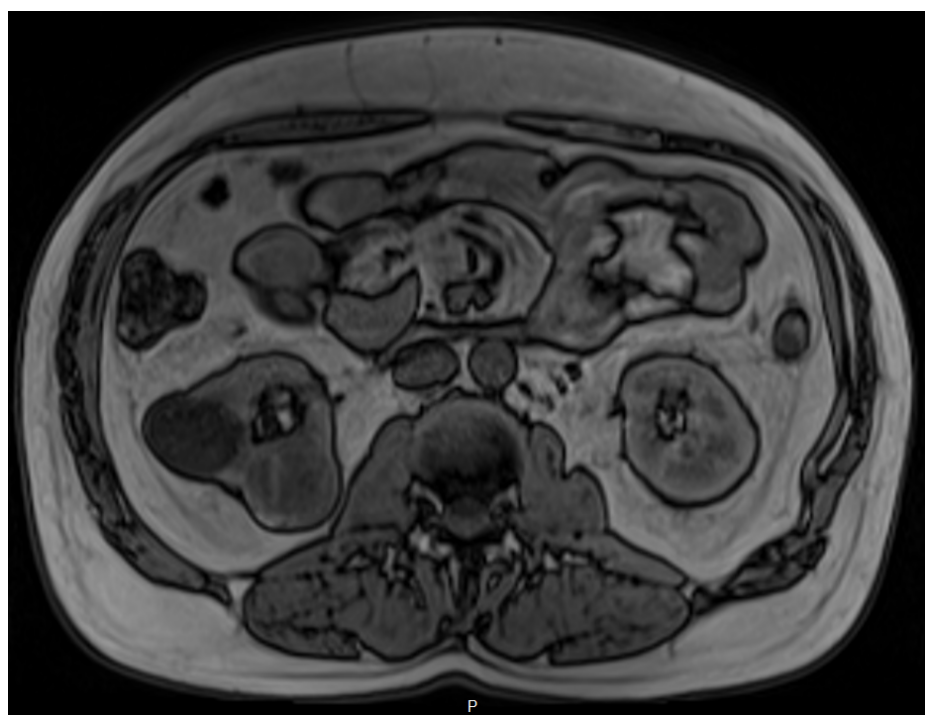

Figure 1. MRI shows a $3.5 \mathrm{~cm}$ solid right renal mass and a $3.5 \mathrm{~cm}$ cystic lesion. 
demarcated lesion was a type 1 papillary renal cell carcinoma with Fuhrman grade 3 (Figure 2), without capsular effraction. In the peri-renal fat overlying the tumor, we observed a focus of viable tumor infiltration associated with a liponecrosis and a granulomatous inflammatory reaction (Figure 3 and Figure 4). The histological finding corresponded to a tumor seeding along the biopsy tract. Immunohistochemically, the tumor seeding cells were positive for both P504s and CK7 (Figure 5). The TNM classification was established as pT3a.

The follow up included a CT-scan 2 days after surgery, 2 months later, 9 months later and finally 4 years after diagnosis. They were all unremarkable.

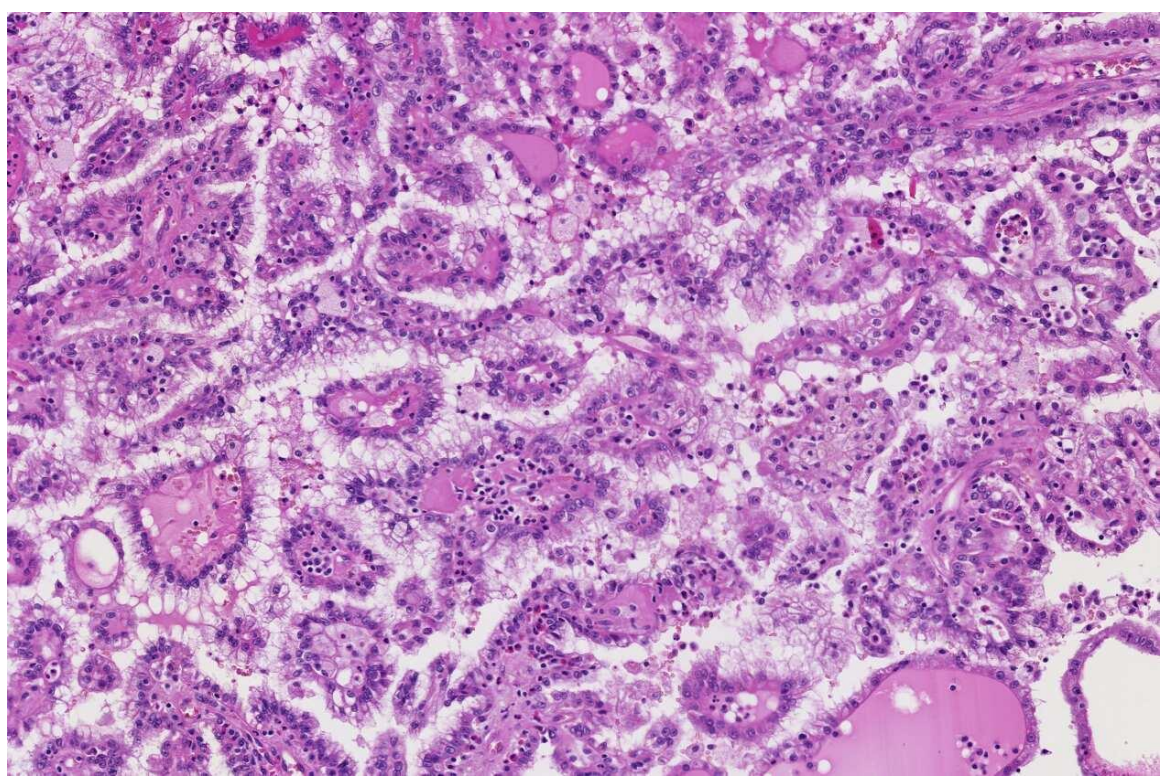

Figure 2. Papillary renal cell carcinoma type 1, characterised by tubulopapillary architecture with admixed foamy histiocytes in the papillary cores (HE staining, 10x).

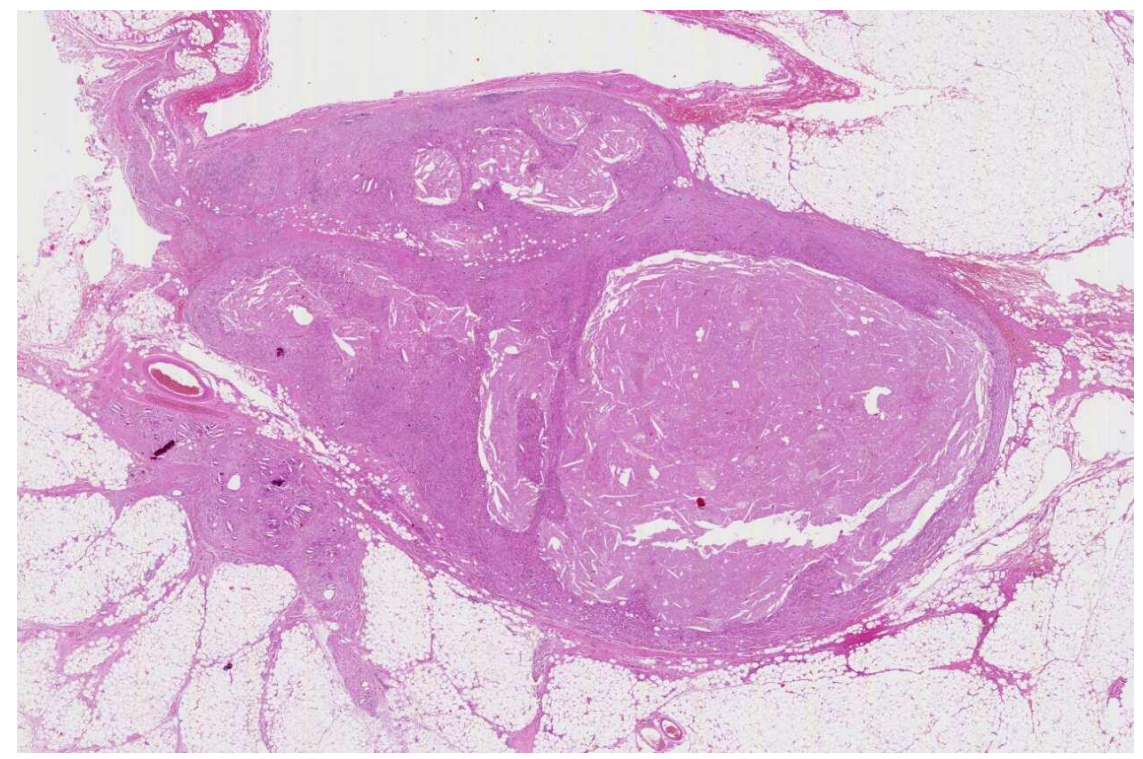

Figure 3. Peri-renal fat overlying the tumor showing the previous percutaneous biopsy tract with tumor seeding. 


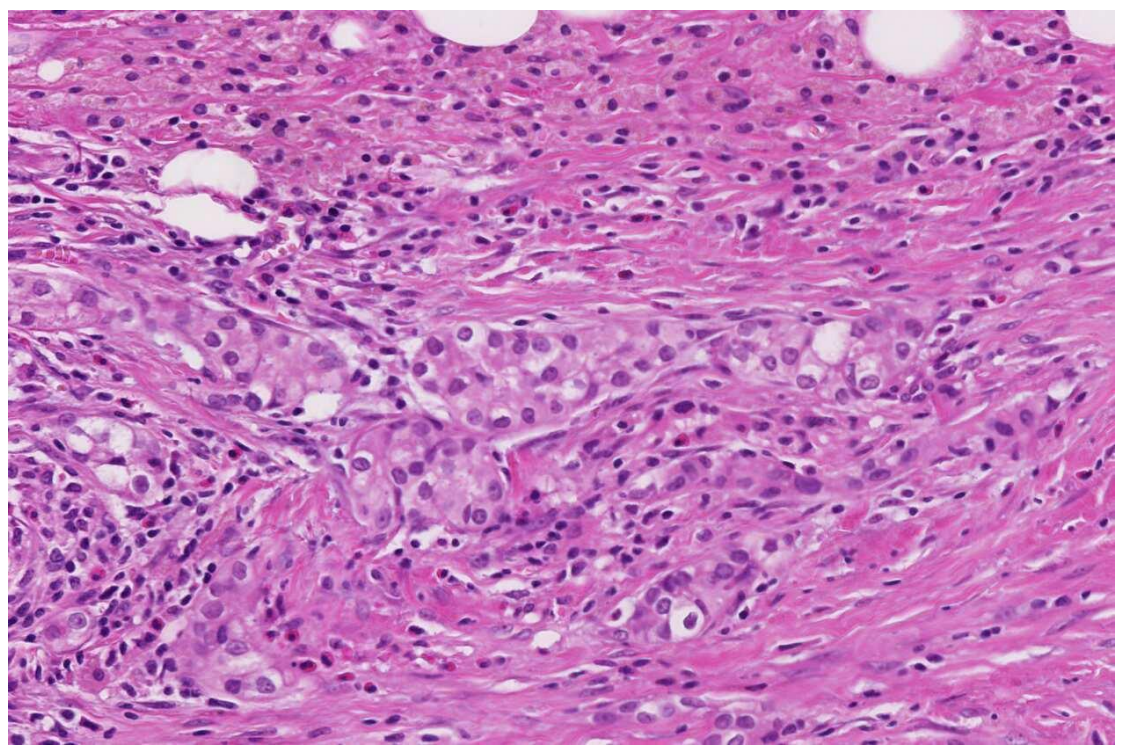

Figure 4. Peri-renal fat overlying the tumor showing papillary renal cell carcinoma seeding along the previous percutaneous biopsy tract (HE staining, 20x).

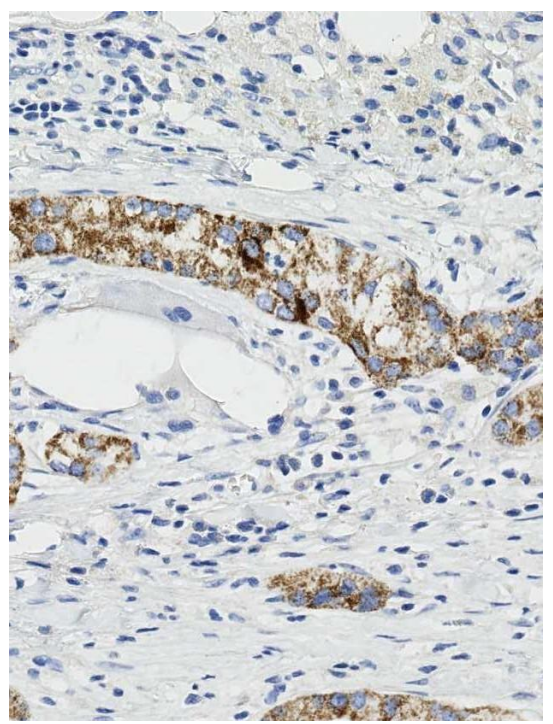

(a)

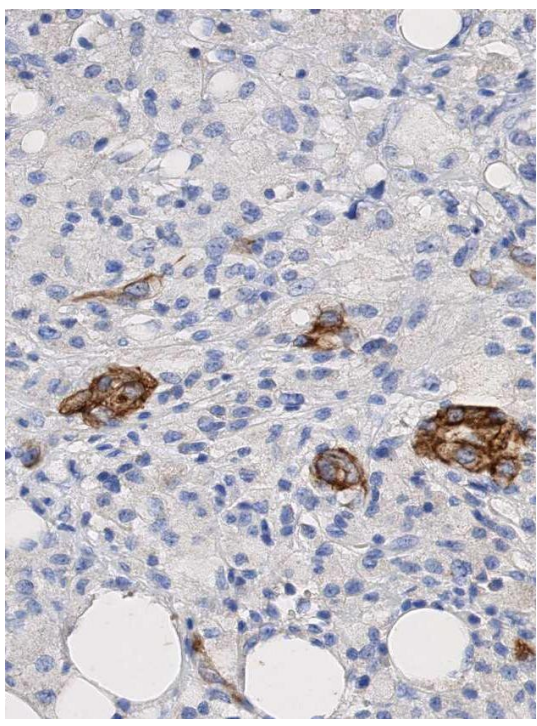

(b)

Figure 5. Tumor seeing cells were positive for P504s (Figure 5(a)) and CK7 (Figure 5(b)), immunohistochemical staining, $20 \times$.

\section{Discussion}

With the development of new biopsy techniques and wider experience of both radiologist and pathologist, the indications of needle core biopsy and fine needle aspiration (FNA) of renal masses are expanding in the diagnosis and management of renal tumors. The percutaneous biopsy of renal masses appears to be safe and accurate [4]. But some potential complications have been observed, including tumor seeding along the needle tract, bleeding, arteriovenous fistula, infection and pneumothorax. Tumor seeding along the needle tract is an extremely rare phenomenon. A review by Herts and Baker in 1995 found that the overall 
estimated risk is less than $0.01 \%$ [9]. To our knowledge only 15 cases have been reported in the literature from 1977 up to nowadays (Table 1) [5] [6] [10]-[20]. As mentioned in Table 1, tumor seeding along the needle tract has been observed with the use of different needle calibre from 14 to 25 gauges, showing no correlation between the risk of seeding and needle size. Some authors believed that the risk may increase with the number of passes (from 1 to 8 passes), noncutting needles and high tumor grade [4] [9]. Unfortunately, most of published data did not mention the number of passes. Several recent series showed no cases of tumor seeding, likely due to better techniques like using coaxial sheath, the widespread use of guiding cannulas and experienced radiologists [7] [8]. Apparently, the current modern techniques can reduce the risk of tumor seeding along the biopsy tract. However, this phenomenon cannot be completely avoided. For our patient, a 18-gauge needle with coaxial sheath was used and

Table 1. Published cases of RCC seeding along a renal percutaneous biopsy tract.

\begin{tabular}{|c|c|c|c|c|c|c|}
\hline Reference (year) & $\begin{array}{l}\text { Coaxial } \\
\text { needle }\end{array}$ & $\begin{array}{l}\text { Needles } \\
\text { size } \\
\text { (gauge) }\end{array}$ & $\begin{array}{c}\text { Number } \\
\text { of } \\
\text { passes }\end{array}$ & $\begin{array}{l}\text { Time to } \\
\text { seeding }\end{array}$ & $\begin{array}{l}\text { Pathological } \\
\text { findings }\end{array}$ & Follow up \\
\hline Gibbons et al. (1977) & No & 18 & N/A & 20 months & RCC & $\begin{array}{l}15 \text { months after seeding, no } \\
\text { recurrence }\end{array}$ \\
\hline Auvert et al. (1982) & No & N/A & N/A & 7 years & Oncocytoma & N/A \\
\hline Wehle et al. (1986) & No & 20 & N/A & 4 years & Papillary RCC & Died 10 month after seeding \\
\hline Kiser et al. (1986) & No & 14 and 20 & N/A & 24 days & Papillary RCC & $\begin{array}{l}18 \text { months after } \\
\text { nephrectomy, no recurrence }\end{array}$ \\
\hline Shenoy et al. (1991) & No & 23 & 7 to 8 & 12 months & RCC & N/A \\
\hline Abe and Saitho (1992) & No & N/A & N/A & 30 months & Angiomyoliposarcoma & N/A \\
\hline Mullins and Rodriguez (2013) & No & 20 and 22 & 6 & 2 months & Papillary RCC & $\begin{array}{l}3 \text { months after nephrectomy, } \\
\text { no recurrence }\end{array}$ \\
\hline Sainani et al. (2013) & Yes & 20 and 25 & N/A & 4 years & Papillary RCC & $\begin{array}{l}7 \text { years after nephrectomy } \\
\text { and cryoablation }\end{array}$ \\
\hline Giordadze et al. (2013) & No & 20 and 22 & N/A & 4 years & Papillary RCC & N/A \\
\hline Chang et al. (2015) & No & 16 and 22 & 2 & 66 days & Clear cell RCC & $\begin{array}{l}6 \text { months after nephrectomy, } \\
\text { no recurrence }\end{array}$ \\
\hline Soares et al. (2015) & Yes & 17 and 18 & 4 & 56 days & Papillary RCC & $\begin{array}{l}1 \text { month after partial } \\
\text { nephrectomy, no recurrence }\end{array}$ \\
\hline Viswanathan et al. (patient A, 2015) & Yes & 19 and 20 & N/A & 10 months & Clear cell RCC & $\begin{array}{l}\text { Died } 2 \text { years after initial } \\
\text { presentation }\end{array}$ \\
\hline Viswanathan et al. (patient B, 2015) & Yes & 19 and 20 & N/A & 2 months & Papillary RCC type 1 & $\begin{array}{l}5 \text { years after biopsy, no } \\
\text { recurrence }\end{array}$ \\
\hline Andersen and Norus (patient A, 2016) & Yes & N/A & N/A & $\begin{array}{c}4 \text { years and } 7 \\
\text { years }\end{array}$ & RCC & N/A \\
\hline Andersen and Norus (patient B, 2016) & N/A & N/A & N/A & $\begin{array}{l}\text { at the time of } \\
\text { nephrectomy }\end{array}$ & RCC & $\begin{array}{l}4 \text { times of local recurrence } \\
\text { between } 2 \text { years and } 4 \text { years } \\
\text { and } 5 \text { months after initial } \\
\text { surgery }\end{array}$ \\
\hline
\end{tabular}


only 2 passes were performed. Tumor seeding along the biopsy tract was observed at the time of nephrectomy. This is the only case in our series of 205 patients of renal biopsies followed by surgery in 17 years. The frequency of tumor needle tract seeding in our series is $0.48 \%(1 / 205)$. The 15 tumor seeding cases after renal biopsy reported in the literature included 6 papillary renal cell carcinoma, 2 clear cell renal cell carcinoma, 1 angiomyoliposarcoma, 1 oncocytoma and 5 without precise histological subtype of RCC [5] [6] [10]-[20]. There is no increase in risk according to the histological type of the renal carcinoma, except for upper tract urothelial carcinoma [4] [7]. The seeding-related recurrences, including our case, were detected from one month to 7 years after the initial biopsy. Among the 15 reported cases, 5 of them did not provide follow up information. The rest of patients have been followed from 1 month to 7 years after the discovery of tumor seeding. The majority of them had a follow-up less than two years without local recurrence. One of the patients had 4 local recurrences which happened between 24 months and 53 months after the initial surgery [20]. Two patients died. One of them died 10 months after the diagnosis of seeding which occurred 4 years after total nephrectomy for a papillary carcinoma. Another patient died 14 months after the discovery of tumor seeding and 10 months after cryoablation for a clear cell renal cell carcinoma with Fuhrman grade 2. The prognosis of patients with tumor seeding along a percutaneous biopsy tract needs to be further explored.

\section{Conclusion}

The use of needle core biopsy in renal masses is expanding to rule out nonrenal cell primary tumors or benign conditions. The risk of tumor seeding along the needle tract appears to be minimal with modern biopsy techniques, but it cannot be completely avoided. We reported a case with tumor seeding along a percutaneous biopsy tract by using an 18-gauge needle with coaxial sheath and only 2 passes. Our case report may contribute to evaluate the prognosis of patients with tumor seeding along a percutaneous biopsy tract.

\section{Conflicts of Interest}

The authors declare no conflicts of interest regarding the publication of this paper.

\section{References}

[1] Lhermitte, B. and de Leval, L. (2012) Interpretation of Needle Biopsies of the Kidney for Investigation of Renal Masses: Review and Perspectives. Virchows Archiv, 461, 13-26. https://doi.org/10.1007/s00428-012-1255-6

[2] Phé, V., Yates, D.R., Renard-Penna, R., Cussenot, O. and Rouprêt, M. (2012) Is There a Contemporary Role for Percutaneous Needle Biopsy in the Era of Small Renal Masses? BJU International, 109, 867-872. https://doi.org/10.1111/j.1464-410X.2011.10544.x

[3] Wang, R. and Wood Jr., D.P. (2009) Evolving Role of Renal Biopsy in Small Renal 
Masses. Urologic Oncology, 27, 332-334.

https://doi.org/10.1016/j.urolonc.2008.12.011

[4] Volpe, A., Kachura, J.R., Geddie, W.R., Evans, A.J., Gharajeh, A., Saravanan, A., et al. (2007) Techniques, Safety and Accuracy of Sampling of Renal Tumors by Fine Needle Aspiration and Core Biopsy. Journal of Urology, 178, 379-386. https://doi.org/10.1016/j.juro.2007.03.131

[5] Sainani, N.I., Talti, S., Anthony, S.G., Shyn, P.B., Tuncali, K. and Silvermann, S.G. (2013) Successful Percutaneous Radiologic Management of Renal Cell Carcinoma Tumor Seeding Caused by Percutaneous Biopsy Performed before Ablation. Journal of Vascular and Interventional Radiology, 24, 1404-1408. https://doi.org/10.1016/j.jvir.2013.04.034

[6] Viswanathan, A., Ingimarsson, J.P., Seigne, J.D. and Schned, A.R. (2015) A Single-Centre Experience with Tumor Tract Seeding Associated with Needle Manipulation of Renal Cell Carcinomas: A Case Report. Canadian Urological Association Journal, 9, 11-12. https://doi.org/10.5489/cuaj.3278

[7] Vasudevan, A., Davies, R.J., Shannon, B.A. and Cohen, R.J. (2006) Incidental Renal Tumors: The Frequency of Benign Lesions and the Role of Preoperative Core Biopsy. BJU International, 97, 946-949. https://doi.org/10.1111/j.1464-410X.2006.06126.x

[8] Tyagi, R. and Dey, P. (2014) Needle Tract Seeding: An Avoidable Complication. Diagnostic Cytopathology, 42, 636-640.

[9] Herts, B.R. and Baker, M.E. (1995) The Current Role of Percutaneous Biopsy in the Evaluation of Renal Masses. Seminars in Urologic Oncology, 13, 254-261.

[10] Gibbons, R.P., Bush Jr., W.H. and Burnett, L.L. (1977) Needle Tract Seeding Following Aspiration of Renal Cell Carcinoma: A Case Report. Journal of Urology, 118, 865-867. https://doi.org/10.1016/S0022-5347(17)58226-9

[11] Auvert, J., Abbou, C.C. and Lavarenne, V. (1982) Needle Tract Seeding Following Puncture of Renal Oncocytoma: A Case Report. Progress in Clinical and Biological Research, 100, 597-598.

[12] Wehle, M.J. and Grabstald, H. (1986) Contraindications to Needle Aspiration of a Solid Renal Mass: Tumor Dissemination by Renal Needle Aspiration. Journal of Urology, 136, 446-448. https://doi.org/10.1016/S0022-5347(17)44900-7

[13] Kiser, G.C., Totonchy, M. and Barry, J.M. (1986) Needle Tract Seeding after Percutaneous Renal Adenocarcinoma Aspiration. Journal of Urology, 136, 1292-1293. https://doi.org/10.1016/S0022-5347(17)45318-3

[14] Shenoy, P.D., Lakhkar, B.N., Ghosh, M.K. and Patil, U.D. (1991) Cutaneous Seeding of Renal Carcinoma by Chiba Needle Aspiration Biopsy: A Case Report. Acta Radiologica, 32, 50-52. https://doi.org/10.1177/028418519103200113

[15] Abe, M. and Saitoh, M. (1992) Selective Renal Tumour Biopsy under Ultrasonic Guidance. British Journal of Urology, 70, 7-11. https://doi.org/10.1111/j.1464-410X.1992.tb15654.x

[16] Mullins, J.K. and Rodriguez, R. (2013) Renal Cell Carcinoma Seeding of a Percutaneous Biopsy Tract. Canadian Urological Association Journal, 7, 176-179. https://doi.org/10.5489/cuaj.499

[17] Giorgadze, T., Qureshi, F., Aulicino, M. and Jacques, S.M. (2013) Retroperitoneal Recurrence of a Stage 1 Renal Cell Carcinoma Four Years Following Core Biopsy and Fine Needle Aspiration: Possible Needle Tract Seeding. Diagnostic Cytopathology, 41, 470-472. https://doi.org/10.1002/dc.22815 
[18] Chang, D.T.S., Sur, H., Lozinskiy, M. and Wallace, D.M.A. (2015) Needle Tract Seeding Following Percutaneous Biopsy of Renal Cell Carcinoma: A Case Report. Korean Journal of Urology, 56, 666-669. https://doi.org/10.4111/kju.2015.56.9.666

[19] Soares, D., Ahmadi, N., Crainic, O. and Boulas, J. (2015) Papillary Renal Cell Carcinoma Seeding along a Percutaneous Biopsy Tract. Case Reports in Urology, 2015, Article ID: 925254. https://doi.org/10.1155/2015/925254

[20] Andersen, M.F.B. and Norus, T.P. (2016) Tumor Seeding with Renal Cell Carcinoma after Renal Biopsy. Urology Case Reports, 9, 43-44.

https://doi.org/10.1016/j.eucr.2016.08.008 